\title{
PSYCHE
}

\begin{tabular}{lll}
\hline VOL. XLV & DECEMBER, 1938 & No. 4 \\
\hline
\end{tabular}

\section{ARE ANT LARVÆ APODOUS?}

\section{By George C. Wheeler}

University of North Dakota

Imms" states that "in all the higher Hymenoptera the prevalent larval type is apodous." Practically, of course, this is true of ant larvæ. But what is one to say of the pairs of small structures found near the posterior border of the ventral surface of each thoracic segment?

A study of the larvæ of some four hundred species of ants in 130 genera representing all of the subfamilies has convinced me such structures are of general occurrence throughout the Family Formicidæ. They are to be found in the subfamilies Dorylinæ, Cerapachyinæ, Ponerinæ, Myrmicinæ, Dolichoderinæ, and Formicinæ. I have not found them in the Pseudomyrminæ, but this may be due to the fact that the ventral surface of the thorax is so complicated by exudatoria and by the trophothylax that a small linear structure might easily be concealed or confused with a wrinkle in preserved material. The solution of the problem requires living specimens. I have not searched for the structures in the Leptanillinæ, partly because the larvæ are so minute and partly because my material is so scarce that I dare not risk any of it at this stage of my study of ant larvæ.

In the literature on ant larvæ I have found no mention of these structures. Imms ${ }^{1}$ says that "vestiges, in the form of papillæ, of what appear to be the remains of thoracic appendages have been detected in Polysphincta and certain other

1Imms, A. D. 1937. Recent advances in entomology (2 ed.). Philadelphia: P. Blakiston's Son and Company, Inc., p. 60 . 
of the Ichneumonoidea." Keilin ${ }^{2}$ has found comparable structures on the apterous larvæ of many families of Diptera. He calls them organes sensoriels vestigiaux des pattes. They are always in the same position on the thoracic segments and they always consist of three or four sensory hairs, which are sometimes mounted on small protuberances. Keilin concludes that they are vestigial legs because of their general occurrence throughout the Diptera; because of the constancy of their form and constitution; because they are found exclusively on the ventral surface of the thoracic segments ; and finally because of their relations to the imaginal buds. This conclusion is in accord with that of Pérez. ${ }^{3}$

Among the ant larvæ these leg vestiges attain their maximum size in the army ants (Dorylinæ). In the genera Dorylus, Eciton, and Cheliomyrmex they are relatively large, subcircular, convex, slightly elevated papillæ. In the mature larvæ of Eciton hamatum (Fabr.) (Fig. 1) and Dorylus (Anomma) wilverthi Emery the diameter of the papilla is $0.05 \mathrm{~mm}$. This is also the size in both young (?) larva (2.8 $\mathrm{mm}$. long) and a mature larva $(5 \mathrm{~mm}$. long) of Cheliomyrmex megalonyx Wheeler. I can find nothing to suggest a sensory function. In $E$. hamatum the surface of the papilla is roughened, but in the other two species it is apparently quite smooth. The close relationship between vestigal legs and imaginal buds is shown in Figs. 2, 3, and 5. In some genera of other subfamilies the vestiges are small transversely elliptical papillæ, but more commonly they appear merely as short transverse lines (grooves or ridges?) which are often difficult to find (Fig. 11). In some genera I have found no trace of the vestiges (e.g., Eusphinctus steinheili Forel and Lioponera luzuriagae Wheeler \& Chapman).

It is not surprising that these vestigial legs have been overlooked in ant larvæ, for in addition to being minute and inconspicuous (except in the Dorylinæ), it is very difficult to distinguish them except in exoskeletons cleaned with a solution of potassium hydroxide and stained with acid fuchsin.

In addition to the vestigial legs I have found some other puzzling structures in ant larvæ. On the mesothorax and

2Keilin, D. 1915. Bull. Soc. France Belgique. 49: 166-173.

3Pérez, C. 1911. C. R. Soc. Biol., Paris. 71: 498-501. 
metathorax there are small paired structures-probably grooves-located one on each side approximately midway between the leg vestige and the spiracle, i.e., ventrolateral and therefore in close proximity to the imaginal buds of the wings. These can hardly be termed wing vestiges since there is no reason for assuming that the ancestral larva had functional wings. They may, however, be the vestiges of wing pads of the nymph of a heterometabolous ancestor. Finally, they may be prothetelous, i.e., adult structures appearing prematurely in the larva. I shall call them provisionally "wing rudiments."

In the male larva of the army ant, Eciton (Acamatus) schmitti Emery (Fig. 4), these wing rudiments appear as short transverse lines (grooves?). They are not present in the worker larva of the same species nor are they to be found in the worker larva of $E$. hamatum. A larva of the Australian bulldog ant, Myrmecia gulosa Fabr. has short $(0.045 \mathrm{~mm}$.) transverse lines (slits?). Similar structures occur in both worker and male larvæ of Cephalotes atratus (L.) and also in the larvæ of Dorymyrmex pyramicus var. flavus McCook. In the sexual larva of Dolichoderus (Hypoclinea) taschenbergi Mayr the wing rudiments have a complicated internal cuticular structure. I can find no evidence of such structures in Cerapachys sp., Paraponera clavata Fabr., or Melophorus bagoti Lubbock.

There is also to be found among ant larvæ a third type of related structure, namely vestigial gonopods. I have so designated them because typically they are paired and located on the ventral surface of the seventh, eighth, and ninth abdominal segments and only on those segments. Gonopods are generally asserted to be the modified appendages of the eighth, ninth, and tenth abdominal segments, but in the larva of Eciton hamatum (Fig. 1) the gonopodal imaginal discs are to be found on the seventh, eighth, and ninth.

As a rule these vestigial larval gonopods are short transverse lines (slits?). Frequently the members of a pair are fused to form a single median line. In Pseudomyrma arboris-sanctæ symbiotica var. lowensohni Forel, however, they are subelliptical papillæ. In some species one or more pairs are apparently lacking, e.g., that of the seventh in 
Melophorus bagoti and that of the ninth in Pseudomyrma loewensohni; in the male larva of Eciton (A.) schmitti there is none on the seventh and eighth and only a very faint trace on the ninth; in Eusphinctus steinheili there is none at all.

It is interesting to note here that these same structures also occur in other aculeate Hymenoptera. Three pairs of vestigial legs, two pairs of wing rudiments, and three pairs of vestigial gonopods (on the seventh, eighth, and ninth abdominal segments) are present in the larvae of the hornet, Vespula (Dolichovespula) maculata (L.) ; of the yellow jackets, Vespula (V.) maculifrons (R. du Buysson) and $V$. (V.) arenaria (Fabr.); of the wasp, Polistes pallipes LePeletier (Fig. 8); and of an undetermined mud dauber (Sphecidæ). I have, however, been unable to find any such structures in the worker honeybee, in the drone honeybee, nor in an undetermined bumblebee.

The leg vestiges in Vespula arenaria (Fig. 7) are open transverse grooves, which fact of itself suggests a possible sensory function. Furthermore one of my sections shows a structure (Fig. 9), which might be nervous, extending from the bottom of this groove to the hypodermis. A section of a gonopodal imaginal disc reveals in the overlying integument a small sensilliform structure (Fig. 6).

Four possible interpretations of these structures have occurred to me. (1) All three types are vestiges: vestigial legs on the three thoracic segments; vestigial abdominal legs (gonopods) on the seventh, eighth, and ninth abdominal segments; and vestigial wing pads on mesothorax and metathorax. (2) All three types are rudiments of adult structures appearing prematurely in these holometabolous larvæ. (3) The six pairs of ventral structures are vestiges, while the two pairs limited to the mesothorax and metathorax are prothetelous rudiments. (4) All are the results of purely developmental processes and limited to the cuticula at the points where the hypodermis first invaginates to form the imaginal buds. Personally I am inclined to prefer the third interpretation. 


\section{EXPLANATION OF PLATES}

Plate 15

Fig. 1. Larva of Eciton hamatum (Fabr.), ventral view, hairs omitted, X 11. Fig. 2. Ventral view of thorax of same showing relation of vestigial legs to the underlying imaginal buds, $\mathrm{X} 42$. Fig. 3 . Parasagittal optical section of same to show relation of vestigial leg to imaginal bud, X 135. Fig. 4. Male larva of Eciton (Acamatus) schmitti Emery, ventral view of thorax, hairs omitted, X 11. Fig. 5 . Larva of Eciton vagans (Olivier), parasagittal section through imaginal bud and vestigial leg, $\mathrm{X} 95 . \mathrm{T}_{1}, \mathrm{~T}_{2}, \mathrm{~T}_{3}$, thoracic segments; $\mathrm{L}_{1}, \mathrm{~L}_{2}, \mathrm{~L}_{3}$, vestigial legs; $\mathrm{C}$, cuticula; $\mathrm{H}$, hypodermis; $\mathrm{W}_{1}, \mathrm{~W}_{2}$, wing rudiments; $G_{1}, G_{2}, G_{3}$, vestigial gonopods.

\section{Plate 16}

Fig. 6. Larva of Vespula ( $V$.$) arenaria, parasagittal section$ through imaginal bud of gonopod, showing sensilla (S), X 138. Fig. 7. Parasagittal section through thorax of same, showing imaginal buds of legs and vestigial legs, X 34. Fig. 8. Larva of Polistes pallipes LePeletier, ventral view, X 6. Fig. 9. Enlargement of mesothoracic portion of Fig. 7, showing nerve (?) to vestigial leg, X 138. Fig. 10. Larva of Pseudomyrma gracilis (Fabr.), ventral view of posterior end, $\mathrm{X} 34 ; \mathrm{A}_{7}, \mathrm{~A}_{8}, \mathrm{~A}_{9}$, seventh, eighth, and ninth abdominal segments. Fig. 11. Larva of Dilobocondyla sp., ventral view of anterior end, X 27. 


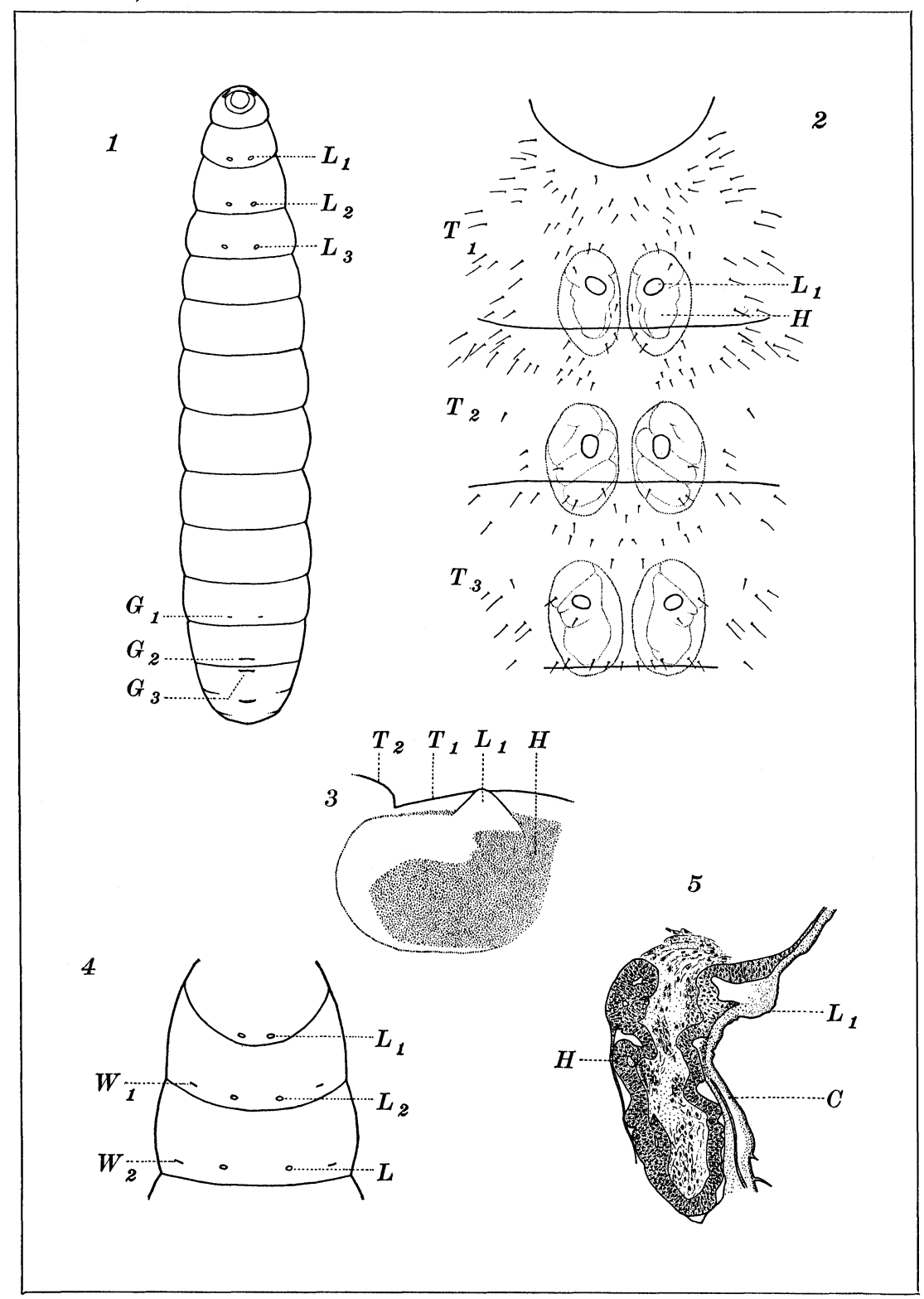

WHEELER - ANT LARVAE 


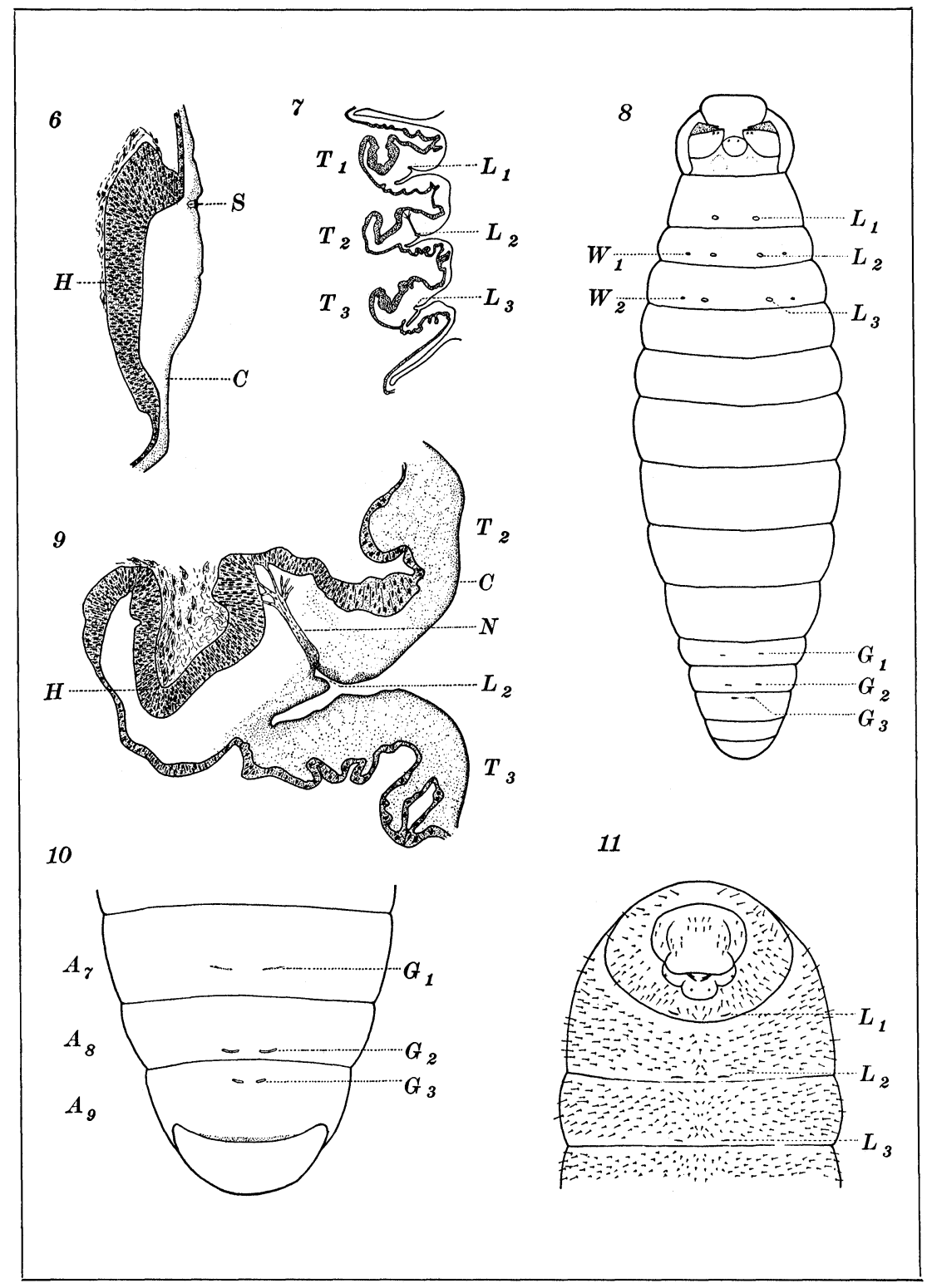

W HEELER - ANT LARV $F$ 

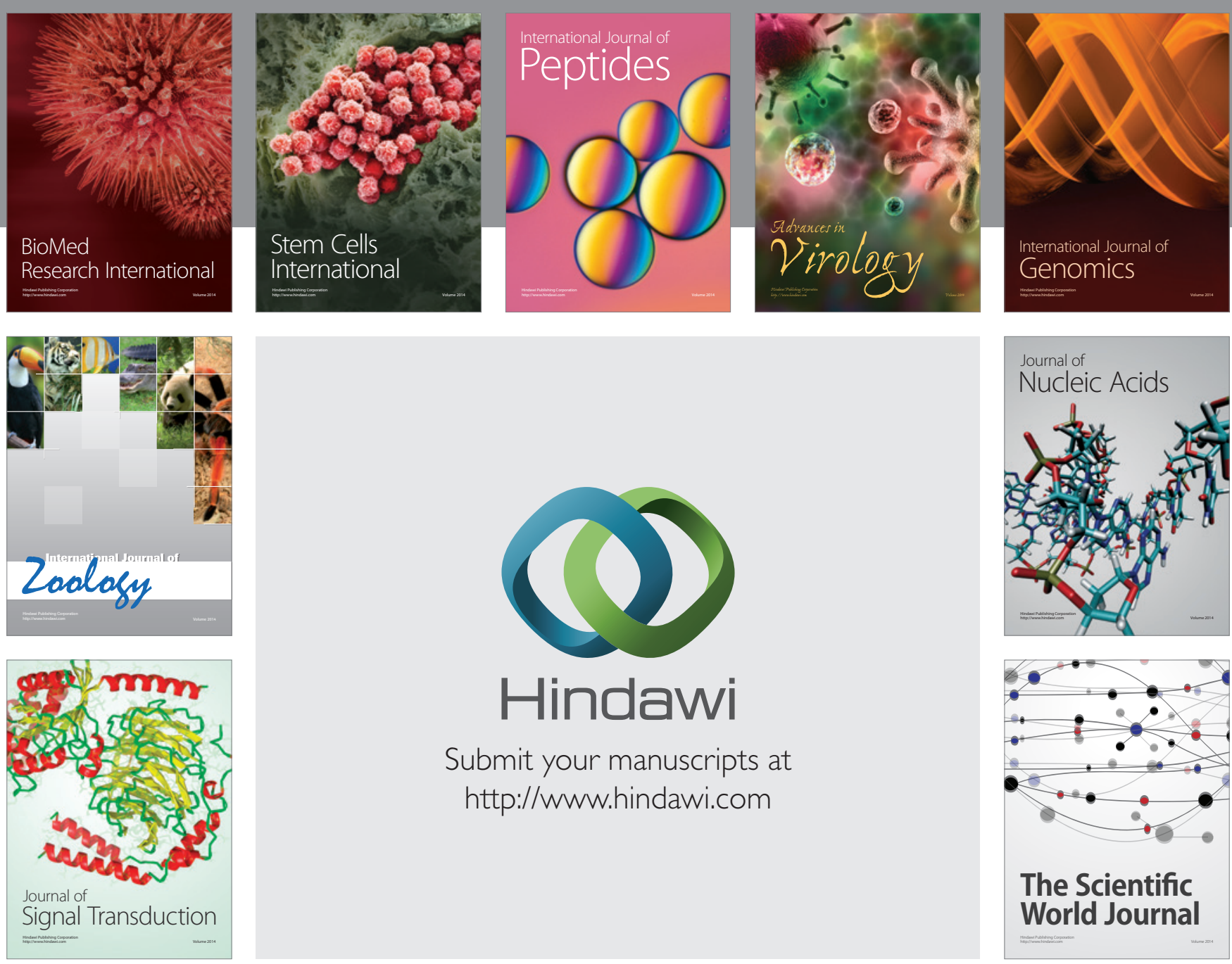

Submit your manuscripts at

http://www.hindawi.com
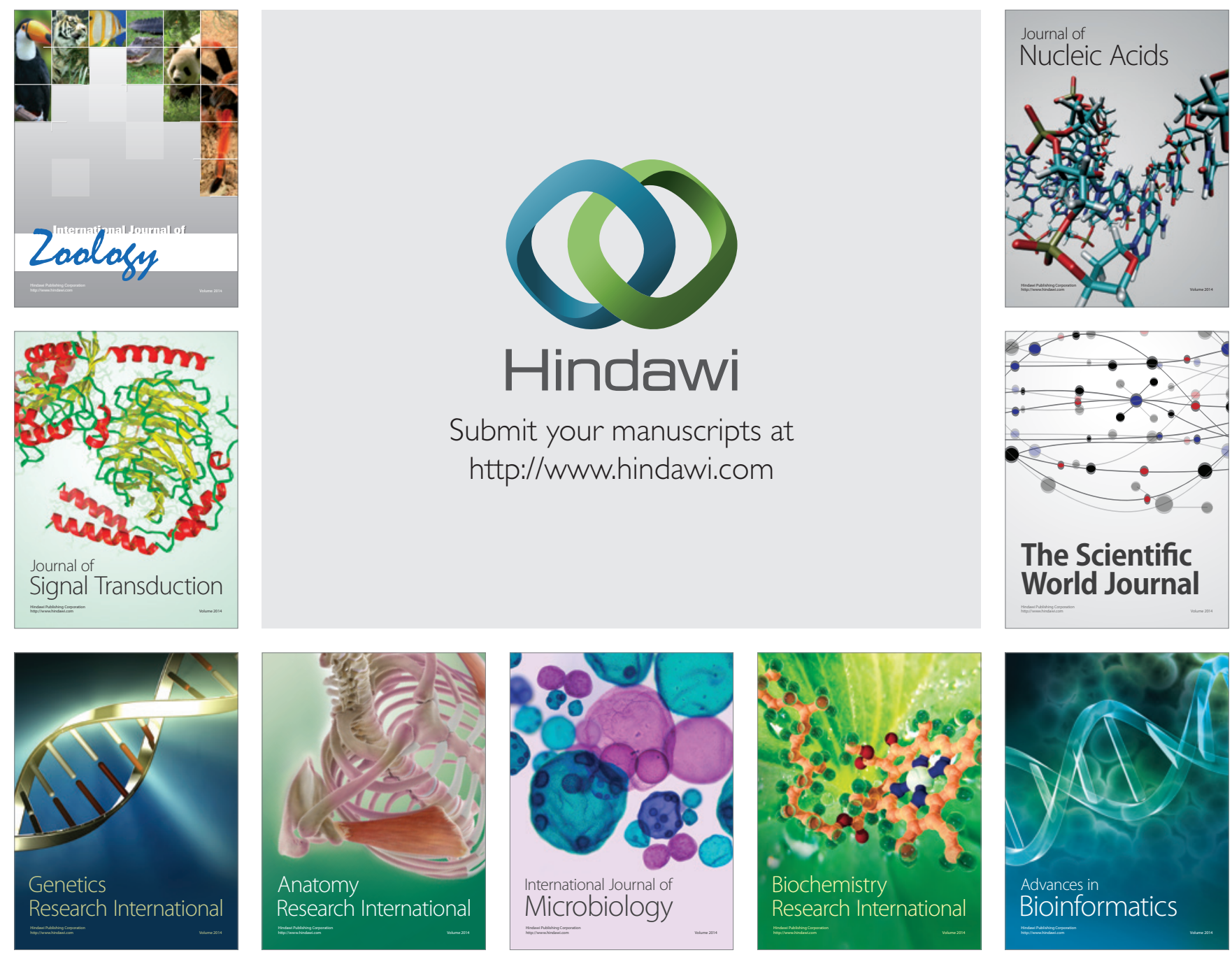

The Scientific World Journal
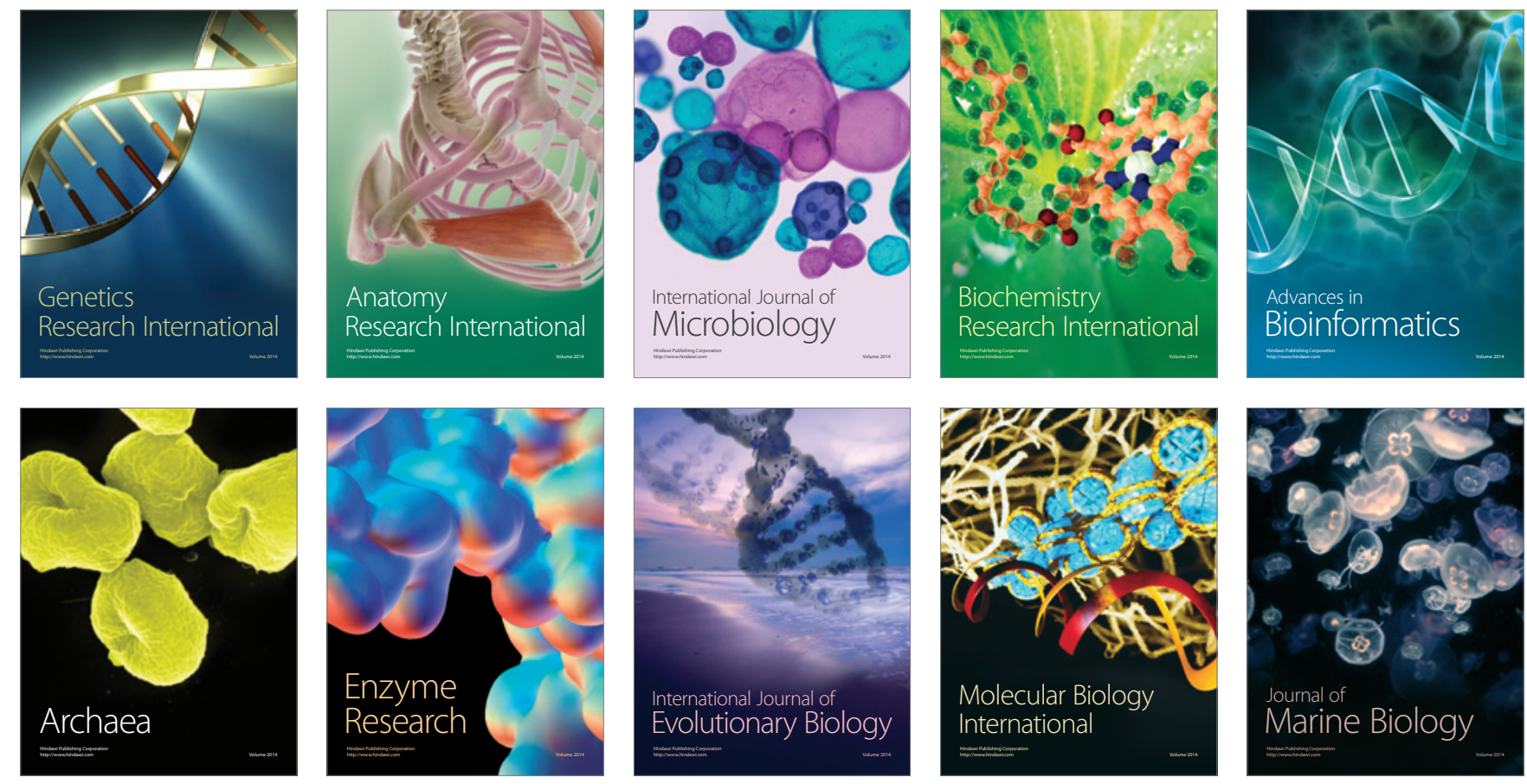